\title{
TIPE DATA ORDINAL
}

\section{MUHAMMAD RIDHO FEBRIAN SAPUTRA} 185110013

Fakultas Komputer

ridhofebrian.student@umitra.ac.id

\begin{abstract}
Bagian lain dari data kontinum adalah data ordinal. Data ini, selain memiliki nama (atribut), juga memiliki peringkat atau urutan. Angka yang diberikan mengandung tingkatan. Ia digunakan untuk mengurutkan objek dari yang paling rendah sampai yang paling tinggi, atau sebaliknya. Ukuran ini tidak memberikan nilai absolut terhadap objek, tetapi hanya memberikan peringkat saja. Jika kita memiliki sebuah set objek yang dinomori, dari 1 sampai n, misalnya peringkat 1, 2, 3, 4, 5 dan seterusnya, bila dinyatakan dalam skala, maka jarak antara data yang satu dengan lainnya tidak sama. Ia akan memiliki urutan mulai dari yang paling tinggi sampai paling rendah. Atau paling baik sampai ke yang paling buruk.
\end{abstract}




\section{A. PENDAHULUAN}

Data Ordinal adalah Bagian lain dari data kontinum. Data ini, selain memiliki nama (atribut), juga memiliki peringkat atau urutan. Angka yang diberikan mengandung tingkatan. Ia digunakan untuk mengurutkan objek dari yang paling rendah sampai yang paling tinggi, atau sebaliknya. Ukuran ini tidak memberikan nilai absolut terhadap objek, tetapi hanya memberikan peringkat saja. Jika kita memiliki sebuah set objek yang dinomori, dari 1 sampai n, misalnya peringkat 1, 2, 3, 4, 5 dan seterusnya, bila dinyatakan dalam skala, maka jarak antara data yang satu dengan lainnya tidak sama. Ia akan memiliki urutan mulai dari yang paling tinggi sampai paling rendah. Atau paling baik sampai ke yang paling buruk.

Misalnya dalam skala Likert (Moh Nazir), mulai dari sangat setuju, setuju, ragu-ragu, tidak setuju sampai sangat tidak setuju. Atau jawaban pertanyaan tentang kecenderungan masyarakat untuk menghadiri rapat umum pemilihan kepala daerah, mulai dari tidak pernah absen menghadiri, dengan kode 5, kadang-kadang saja menghadiri, dengan kode 4, kurang menghadiri, dengan kode 3 , tidak pernah menghadiri, dengan kode 2 sampai tidak ingin menghadiri sama sekali, dengan kode 1. Dari hasil pengukuran dengan menggunakan skala ordinal ini akan diperoleh data ordinal. Alat analisis (uji hipotesis asosiatif) statistik nonparametrik yang lazim digunakan untuk data ordinal adalah Spearman Rank Correlation dan Kendall Tau. 


\section{B. PEMBAHASAN/STUDI KASUS}

Bagian lain dari data kontinum adalah data ordinal. Data ini, selain memiliki nama (atribut), juga memiliki peringkat atau urutan. Angka yang diberikan mengandung tingkatan. Ia digunakan untuk mengurutkan objek dari yang paling rendah sampai yang paling tinggi, atau sebaliknya. Ukuran ini tidak memberikan nilai absolut terhadap objek, tetapi hanya memberikan peringkat saja. Jika kita memiliki sebuah set objek yang dinomori, dari 1 sampai $\mathrm{n}$, misalnya peringkat $1,2,3,4,5$ dan seterusnya, bila dinyatakan dalam skala, maka jarak antara data yang satu dengan lainnya tidak sama. Ia akan memiliki urutan mulai dari yang paling tinggi sampai paling rendah. Atau paling baik sampai ke yang paling buruk.

Misalnya dalam skala Likert (Moh Nazir), mulai dari sangat setuju, setuju, ragu-ragu, tidak setuju sampai sangat tidak setuju. Atau jawaban pertanyaan tentang kecenderungan masyarakat untuk menghadiri rapat umum pemilihan kepala daerah, mulai dari tidak pernah absen menghadiri, dengan kode 5, kadang-kadang saja menghadiri, dengan kode 4, kurang menghadiri, dengan kode 3 , tidak pernah menghadiri, dengan kode 2 sampai tidak ingin menghadiri sama sekali, dengan kode 1. Dari hasil pengukuran dengan menggunakan skala ordinal ini akan diperoleh data ordinal. Alat analisis (uji hipotesis asosiatif) statistik nonparametrik yang lazim digunakan untuk data ordinal adalah Spearman Rank Correlation dan Kendall Tau.

Tipe ordinal mempunyai 5 jenis data, yaitu :

\section{- Tipe Integer}

Dalam bahasa pemrograman, tipe data integer adalah tipe data yang terdiri dari angka bulat (tidak mengandung nilai pecahan atau nilai desimal). Nilai ini bisa berbentuk angka positif maupun negatif, contohnya $1,2,6$, 44, 20000, atau 128730123.

Pascal mendukung beragam tipe data integer, seperti byte, shortint, smallint, word, integer, cardinal, longint, longword, int64, dan qword. Tipe-tipe ini dibedakan berdasarkan jangkauan nilai dan kapasitas memory yang dibutuhkan.

Tipe Integer
\begin{tabular}{|l|c|}
\hline \multicolumn{1}{|c|}{ Tipe } & Batas nilai \\
\hline Shortint & $-128 \ldots 127$ \\
\hline Integer & $-32768 \ldots 32767$ \\
\hline Longint & $-2147483648 \ldots 2147483647$ \\
\hline Byte & $0 \ldots 255$ \\
\hline Word & $0 \ldots 65535$ \\
\hline
\end{tabular}

Operator pada tipe data integer
\begin{tabular}{|c|c|}
\hline Operator & Arti \\
\hline+ & Penjumlahan \\
\hline- & Pengurangan \\
\hline$*$ & Perkalian \\
\hline div & Pembagian \\
\hline mod & Sisa pembagian \\
\hline
\end{tabular}




\section{- Tipe Boolean}

Tipe data boolean sebenarnya sangat serderhana. Tipe data ini hanya bisa diisi dengan salah satu dari 2 nilai: TRUE atau FALSE. Tipe data boolean banyak digunakan untuk percabangan kode program, atau untuk memutuskan apa yang mesti dijalankan ketika sebuah kondisi terjadi.

Sebagai contoh, kita bisa membuat kode program untuk menentukan apakah sebuah angka genap atau ganjil berdasarkan input dari pengguna. Untuk keperluan ini kita harus mengecek terlebih dahulu apakah angka itu bisa dibagi 2 (untuk angka genap), atau tidak bisa dibagi 2 (untuk angka ganjil). Tipe data boolean bisa digunakan untuk menampung kondisi seperti ini, benar atau salah (True atau False).

Contoh penggunaan tipe data boolean akan lebih jelas jika anda telah mempelajari kondisi percabangan program seperti IF (yang akan saya jelaskan pada tutorial terpisah). Untuk sementara anda hanya perlu memahami bahwa tipe data boolean adalah tipe data yang hanya memiliki 2 isi: TRUE atau FALSE.

Berikut contoh penggunaan data boolean :

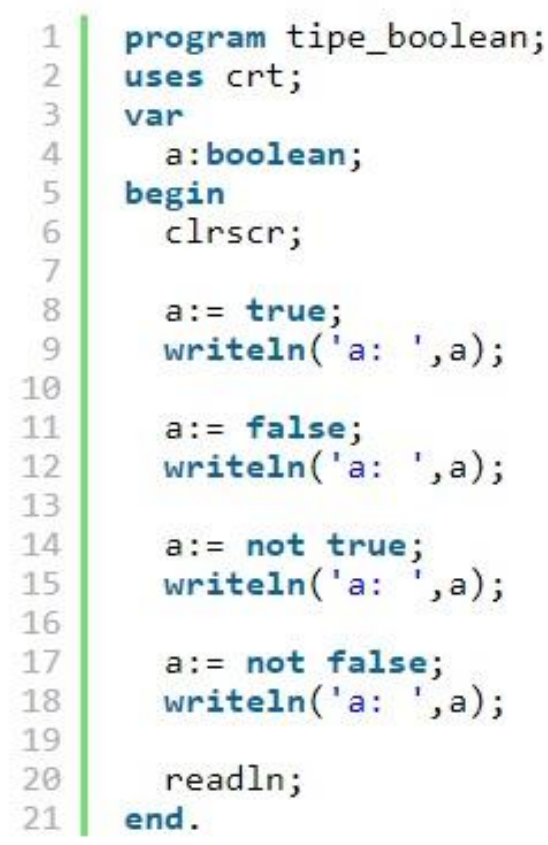

\section{- Tipe Char (Character)}

Tipe data Char adalah tipe data yang hanya bisa diisi dengan 1 karakter saja. Karakter ini harus ditulis diantara tanda kutip. Karena hanya bisa diisi dengan 1 karakter saja, tipe data char hanya membutuhkan 1 byte memory ( 1 byte $=8$ bit $)$.

Selain itu, variabel bertipe data char juga bisa diisi dengan urutan karakter ASCII. Ini akan lebih mudah dijelaskan dengan menggunakan contoh kode program.

Di dalam compiler FreePascal, selain tipe data Char, didukung juga tipe data AnsiChar dan WideChar. 
Berikut contoh penggunaan tipe Char :

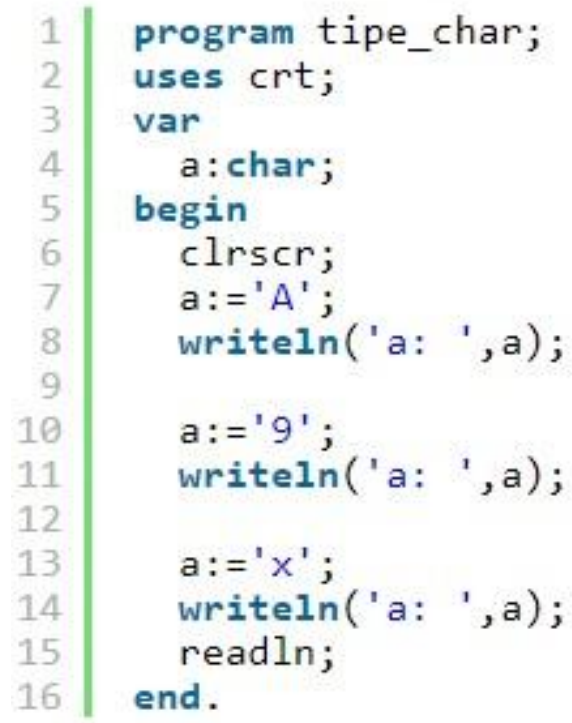

\section{- Tipe Subrange(Subjangkauan)}

Sesuai dengan namanya, tipe data subrange merupakan tipe data bentukan yang berasal dari bagian (sub) tipe data lain yang berada dalam sebuah jangkauan (range).

Sebagai contoh, kita bisa membatasi sebuah tipe data "satuan" dimana hanya bisa diisi dengan angka 1 hingga 9. Angka 1 sampai dengan 9 merupakan bagian (sub) dari tipe data integer. Jika kita mencoba mengisi tipe data "satuan" ini dengan angka selain 1-9, Pascal akan memberikan error.

Cara Penggunaan Tipe Data Subrange

Untuk membuat tipe data subrange, caranya hampir sama dengan tipe data enumerated, dimana kita harus mendefenisikannya di bagian type, kemudan baru membuatnya sebagai variabel di bagian var. Berikut contohnya:

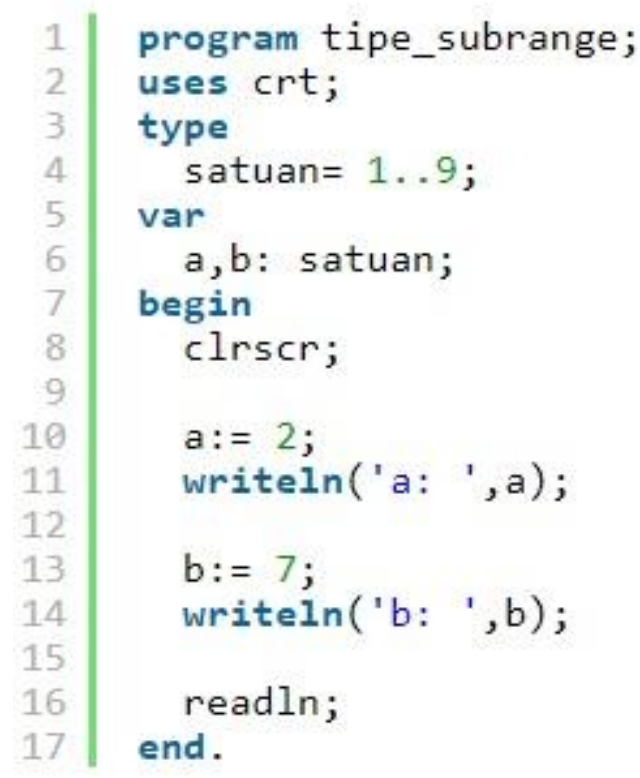

\section{- Tipe Terbilang}

Disebut tipe data terbilang karena semua nilai disebut satu persatu. Contoh : dalam suatu kampong terdapat 5 buah toklo kelontong, karena akan dilakukan pendataan/komputasi nama dan jumlah took di desa maka nama toko tersebut dapat digunakan untuk mendefenisikan tipe daya yang baru, yaitu :

TypeToko

$=($ BARU,RAMAI,SUKSES,RAPI,GA

DJAH); 
Data baru dengan tipe Toko dapat digunakan untuk menjelaskan perubah lain yang bertipe Toko; hal ini memungkinkan kita untuk memakai nama-nama toko dalam program.

\section{ID SECURITY}

QWTD4452377-ASP-5244107

\section{KESIMPULAN}

Jadi, data ordinal adalah bagian lain dari data kontinum. Data ini, selain memiliki nama (atribut), juga memiliki peringkat atau urutan. Angka yang diberikan mengandung tingkatan. Ia digunakan untuk mengurutkan objek dari yang paling rendah sampai yang paling tinggi, atau sebaliknya. Ukuran ini tidak memberikan nilai absolut terhadap objek, tetapi hanya memberikan peringkat saja. Jika kita memiliki sebuah set objek yang dinomori, dari 1 sampai $n$, misalnya peringkat 1, 2, 3, 4, 5 dan seterusnya,

\section{E. DISKUSI}

Saya bersama teman saya mendiskusikan hasil dari materi ini dengan sangat baik.

Saya : apakah artikel ini membantu anda?

Nando: iya artikel ini sangat membantu.
Saya : kenapa artikel ini sangat membantu anda?

Nando: karena artikel ini menjelaskan tentang pengertian Data Ordinal, cara penggunaannya, dan jenis jenis nya, sehingga saya bisa mempelajarinya dari artikel ini.

Saya : terima kasih sudah menyukai artikel ini.

\section{F. REFERENCE}

[1] O. M. Febriani and A. S. Putra, "Sistem Informasi Monitoring Inventori Barang Pada Balai Riset Standardisasi Industri Bandar Lampung," J. Inform., vol. 13, no. 1, pp. 90-98, 2014.

[2] A. S. Putra, "Paperplain: Execution Fundamental Create Application With Borland Delphi 7.0 University Of Mitra Indonesia," 2018.

[3] A. S. Putra, "2018 Artikel Struktur Data, Audit Dan Jaringan Komputer," 2018.

[4] A. S. Putra, "ALIAS MANAGER USED IN DATABASE DESKTOP STUDI CASE DB DEMOS."

[5] A. S. Putra, "COMPREHENSIVE SET OF PROFESSIONAL FOR DISTRIBUTE COMPUTING."

[6] A. S. Putra, "DATA ORIENTED RECOGNITION IN BORLAND DELPHI 7.0."

[7] A. S. Putra, "EMBARCADERO DELPHI XE 2 IN GPUPOWERED FIREMONKEY APPLICATION." 
[8] A. S. Putra, "HAK ATAS KEKAYAAN INTELEKTUAL DALAM DUNIA TEKNOLOGY BERBASIS REVOLUSI INDUSTRI 4.0."

[9] A. S. Putra, "IMPLEMENTASI PERATURAN PERUNDANGAN UU. NO 31 TAHUN 2000 TENTANG DESAIN INDUSTRI BERBASIS INFORMATION TECHNOLOGY."

[10] A. S. Putra, "IMPLEMENTATION OF PARADOX DBASE."

[11] A. S. Putra, "IMPLEMENTATION OF TRADE SECRET CASE STUDY SAMSUNG MOBILE PHONE."

[12] A. S. Putra, "IMPLEMENTATION PATENT FOR APPLICATION WEB BASED CASE STUDI WWW. PUBLIKLAMPUNG. COM."

A. S. Putra, "IMPLEMENTATION SYSTEM FIRST TO INVENT IN DIGITALLY INDUSTRY."

[14] A. S. Putra, "MANUAL REPORT \& INTEGRATED DEVELOPMENT

ENVIRONMENT BORLAND DELPHI 7.0."

[15] A. S. Putra, "PATENT AS RELEVAN SUPPORT RESEARCH."

[16] A. S. Putra, "PATENT FOR RESEARCH STUDY CASE OF APPLE. Inc."

[17] A. S. Putra, "PATENT PROTECTION FOR APPLICATION INVENT."

[18] A. S. Putra, "QUICK REPORT
IN PROPERTY PROGRAMMING."

[19] A. S. Putra, "REVIEW CIRCUIT LAYOUT COMPONENT

REQUIREMENT ON ASUS NOTEBOOK."

[20] A. S. Putra, "REVIEW TRADEMARK PATENT FOR INDUSTRIAL TECHNOLOGY BASED 4.0."

[21] A. S. Putra, "TOOLBAR COMPONENT PALLETTE IN OBJECT ORIENTED PROGRAMMING."

[22] A. S. Putra, "WORKING DIRECTORY SET FOR PARADOX 7."

[23] A. S. Putra, "ZQUERY CONNECTION

IMPLEMENTED

PROGRAMMING STUDI CASE PT. BANK BCA Tbk."

[24] A. S. Putra, D. R. Aryanti, and I. Hartati, "Metode SAW (Simple Additive Weighting) sebagai Sistem Pendukung Keputusan Guru Berprestasi (Studi Kasus: SMK Global Surya)," in Prosiding Seminar Nasional Darmajaya, 2018, vol. 1, no. 1, pp. 85-97.

[25] A. S. Putra and O. M. Febriani, "Knowledge Management Online Application in PDAM Lampung Province," in Prosiding International conference on Information Technology and Business (ICITB), 2018, pp. 181-187.

[26] A. S. Putra, O. M. Febriani, and B. Bachry, "Implementasi Genetic Fuzzy System Untuk Mengidentifikasi Hasil Curian Kendaraan Bermotor Di Polda 
Lampung," SIMADA (Jurnal Sist. Inf. dan Manaj. Basis Data), vol. 1, no. 1, pp. 21-30, 2018.

[27] A. S. Putra, H. Sukri, and K. Zuhri, "Sistem Monitoring Realtime Jaringan Irigasi Desa (JIDES) Dengan Konsep Jaringan Sensor Nirkabel," IJEIS (Indonesian J. Electron. Instrum. Syst., vol. 8, no. 2, pp. 221-232.

[28] D. P. Sari, O. M. Febriani, and A. S. Putra, "Perancangan Sistem Informasi SDM Berprestasi pada SD Global Surya," in Prosiding Seminar Nasional Darmajaya, 2018, vol. 1, no. 1, pp. 289-294. 